\title{
Analyzing Conversation in Children's Short Stories
}

\author{
Instructor: Nagham Ali Hassan
}

\section{Baghdad University/ College of Engineering/ Environmental Engineering Department}

\begin{abstract}
:
Conversation analysis has long been the concern of many linguists who work in the field of discourse analysis. In spite of the fact that there are many researches have been done in the field of short stories but up to the researcher knowledge the investigation of the selected short stories has not been studied yet. Hence, this paper aims at answering the following questions: what are the features of children's short stories language and the differences between short stories of four years old and those of six years old. Hence, the devices used by the story tellers in reciting the short stories should be observed. Thus, the researcher has consulted the models presented by Johnson and Fillmore (2010) to show tenses and sentence structure, and Smith (2008) for conversation analysis.
\end{abstract}

In the light of the analysis according to Johnson and Fillmore (2010), the researcher has reached to the following results: It is clear that simple sentences and past simple tense are used more than the other devises due to the fact that it is the main features of children's short stories language. The conversation of children's short stories has also showed that the language of four years old is somehow similar to those of six years old. According to Smith (2008), it is clear that the language of children is similar to those of short stories then it is similar to those of real life conversation.

\section{Introduction:}

Oral narrative (i.e. written to be spoken) is a term that covers a number of different types of storytelling. Spontaneous conversational narrative (natural narrative) institutionalized oral narrative in an oral culture context, oral story, simulation of orality in written text by means of narrative strategies such as: pseudo-orality. The text has orally transmitted storytelling are used to analyze the deep structure of narrative to discover functions of plot elements and typical structure of narrative (Fluedmik, 2012: 2)

In this research there are eight stories, four stories for children four years old and four stories for children six years old. The data is taken from <www.Sparknote.com> retrieved on 3/8/2014. The model adopted is Johnson and Fillmore (2010) to analyze sentence structure and function, and for tenses from the website (www.melta.org.my) retrieved on 3/8/2014. The researcher finds that these models cannot serve alone in representing 
the communication field; so, there is another model which is represented by Smith (2008) from the web site (www.melta.org.my)for conversation analysis retrieved on 3/8/2014. The study will depend on oral conversation and neglects the pictures. Every short story has a number and within each short story, each sentence includes a number. The analysis is done in a table for clarification.

\section{Extratextual Interaction}

The extratextual interactions involved in the stories were coded on the basis of content and were examined separately for parents and children. The specific procedure presented by (Marry, 1997: 46) involves the following extratextual interaction categories:

1. Attention: Extratextual interaction with a view to draw children's attention (by calling the children's names: "Can you hear, Irene?" or by drawing their attention to illustrations: "Can you see the dog?")

2. Names: Extratextual interaction with a view to make children familiar with the names of objects, incidents, characters, and setting ("This is a lion.")

3. Asking about names: Questions about the names of objects, incidents, characters, etc., of the story ("What is she wearing on her head?" "Where is the lion caged?")

4. Feedback: Extratextual interaction that aims at praising, confirming, or correcting children's extratextual interaction ("Yes, Snow White was pretty." "No, he was not dropping pebbles; he was dropping crumbs.")

5. Repetition: Verbatim repetition of children's words or phrases (child: "a dog"; parent: "a dog")

6. Elaboration: Extratextual interaction through which child's words or phrases are elaborated by adding extra information (child: "a bee"; parent: "a flying bee")

7. Organizing the activity: Extratextual interaction through which children are kept intrigued by the story ("I'm going ahead.")

8. Prediction. Questions asked to a child with a view to give information about facts and incidents in the story that have not yet been told ("What did the animals do next?") 
9. Relating the story to real life: Commentary questions to children with a view to relate the plot of the story to everyday experience and inform them about facts and objects in the story ("What color is your own toothbrush?" "We drive a car; they used to drive a car."

10. Recalling information. Questions are raised to children in order to make them recall incidents and details in the story.

11. Clarifying. Extratextual interaction with a view to motivate picture description, word explanation, and interpretation of characters' attitudes.

\section{Children's Short Stories:}

Applebee (1978: 7) states that story tellers must be careful not to give conclusion instead of information, because children should have a space to make up their own minds.

He (ibid) adds that young children are often visual. This enables them to participate in the story. Children's stories are full of pictures i.e. story loses words instead to gain pictures. Children's notification is often photo lead with the bulk of the information coming through pictures.

Cain and Oakillj(1990:26) mention that children understand the stories better if they are shown through pictures because abstract concepts are difficult when draw conclusion, then passed over in the child's understanding.

Marry (1997: 28) notices that conversation has two types: either person talks and the child listen or the child read the story. Here conversation will lose the medium which is represented by the speaker. He adds that structure should be simple i.e. a sentence does not always need to be short, but it should be grammatically simple. Complex and compound clauses will frustrate and confuse readers. Sentence fragments must be very clear if used. There should be the slightest confusion over who speaks the dialogue or who is referred to by pronoun. One common "clue" for spotting reader's material is speech tags which are simple and abundant.

Peterson and Dodswory (1991:67) observe that vocabulary should be easy so that the child understands the spoken or the written form i.e. the child can understand the meaning of words throughout the context. 
Peterson and Mc Cabe (1997:89) mention that children understand the difference between realty and imagination. Fancy stories begin to be popular for children at this age. Children are often introduced to folktales.

Yuill and Joscelyne (1988:39) state those stories no longer need to be specific to the child's world. Founts readers are especially interested in the exotic and space they are not experiences. These are the topics that capture children's mind because they feed both his curiosity and his imagination.

\section{Narrative in Short Stories:}

Labov (1972:56) mentions that narrative is not any talk about the past, or any talk about event, it is specifically talk in which a sequence of clauses is matched to a sequence of events which is inferred actually occurred.

Shapiro and Hudson (1997:37) state that narrative production has been used extensively to investigate developmental differences in children's story knowledge and their ability to produce structurally coherent stories. The body of the work demonstrates considerable change during the early school years. Conventional features of stories such as formal opening "once upon a time" and ending "and they all lived happily ever after" indicate knowledge of the narrative form. These story conventions occur more frequently in the narrative produced by 6 and 8 years old than in those produced by preschooler's.

Dodsworth (1990:36) mentions that children with several years of experience of reading and listening to stories will have had more exposure to story convention. This makes them recall all of stories than preschool. This indicates that tact knowledge of the structural importance of story units is related to general reading ability

Cain and Oakhillj (1990:58) note that narrative production is used in school to develop children's reading and writing skills however give the strong relation that exists between age and the organization of narrative and the proposed relation between reading ability and story knowledge.

\section{Features of Children's Short Stories:}

Here are the elements that editor, reviewers, and to some extent readers will look for in the story as mentioned by Peterson and McCabe (1997:15): 
1. Theme: A theme is an insight view points or concept that a story conveys. Children's stories should be exploration of life. If writing about a social problem, offer constructive ways in simple structure.

2. Plot: plot is normally built around a conflict involving the main character for instance with another character, or with circumstances. A story may succeed without conflict especially if for preschoolers using simple vocabulary.

3. Story structure: keep the structure as simple as possible. In picture book keep the action in chronological order without flash back (insertion of earlier scenes). For narration make the best choice for the story between "first person and third person". The former for the story is told by one of its character the latter it is told as if by an outside observer.

4. Write simply and directly in words, short sentences, and short paragraphs use dialogue wherever possible. Use direct quotes instead of indirect e.g. "Go away" instead of "He told her to go away" convey information throughout dialogue. Use language that creates an atmosphere suited to the story.

\section{Children's Grammar:}

As children listen to people talk, they hear many normal utterances i.e. the children encounter only performance, yet all of them develop competence from their exposure to language. They learn to create and to understand new sentences. It seems almost certain that each child has some innate ability for working with the raw language materials he finds in his environment for developing them into his grammar (Liles, 1971:81).

Johnstone (2001: 641) states that grammar tends to be simple and relatively ironic, avoiding such strategies as passivization and subordination. Moreover, he examines how developing expertise in remembering and representing events constructing narrative macrostructure, using tense, aspect, pronoun, and interpreting the context all come together as children mature.

\section{The Adopted Model:}

In this research, the researcher adopts Johnson and Fillmore (2010) to analyze sentence structure and function, and for tenses from the website (www. Melta.org.my). The researcher finds that these models cannot serve alone in representing the communication field; so, there is another model 
which is represented by Smith (2008) from the website (www. Melta.org.my)for conversation analysis. Since, it is very important to categorize this aspect.

\subsection{Sentences:}

According to Johnson and Fillmore (2010:4) Sentences are a means of expressing oneself through the use of clauses, words and thoughts. Linguistically, a sentence can be defined as "an expression that indicates a grammatical unit consisting of one or more words that generally bear minimal syntactic relation to the words that precede or follow it", question, exclamation, request or command. Furthermore, a sentence can be classified into different types on the basis of two categories: structure and purpose. Glance through the lines below to find out the various kinds of sentences in English language.

\subsubsection{Different Kinds of Sentences:}

\section{A: On the Basis of Structure:}

Johnson and Fillmore (2010:14) states that on the basis of structure the sentences can be classified as

\section{Simple Sentences}

A simple sentence comprises of one independent clause and has no dependent clauses. Sentences like 'some students like to study in the mornings' is an example of simple sentence. Johnson and Fillmore (2010: 17) present sentence patterns as:

1. SVA: Mary is in the house.

2. SVCs: Mary is kind.

3. SVO: Somebody caught the ball.

4. SVOA: I put the plate on the table.

5. SVOC: We have proved him a fool.

6. SVOO: She gives me expensive present.

7. SV: The child laughed. 


\section{Compound Sentences}

According to Johnson and Fillmore (2010: 20) a compound sentence contains two independent clauses that are linked by a coordinator or conjunction. This conjunction can be any one of the three links, namely coordinating conjunction (for, and, but, not, yet, etc.), conjunctive adverbs (however, therefore, while, etc.) and a semicolon. An example of compound sentences 'Tom ate the cake and Jerry ate the chips', 'Alejandro played football while Maria went shopping' and 'I had a parry; John did not come'. Here, 'Tom', 'Jerry', 'Alejandro', 'Maria', 'I' and 'John' are independent clauses, while the words 'and', 'while' and the semicolon are coordinators.

\section{Complex Sentences}

According to Johnson and Fillmore (2010: 23) a complex sentence contains an independent clause connected by one or more dependent clauses. Additionally, it also has a subordinator or subordinating conjunction, such as: although, because, since, after and when, or a relative pronoun such as that, who or which. In case the sentence begins with a subordinator, a comma is placed after the end of the dependent clause. The following sentences are fine examples of complex sentences.

The teacher returned the homework after she noticed the error.

After they finished studying, Juan and Maria went for a movie.

The students are studying because they have a test tomorrow.

\section{Complex-Compound Sentences}

A complex-compound sentence or a compound-complex sentence contains at least two independent clauses and at least one dependent clause. Consider the following example:

I had a table, chair and computer for my work, but my boss, who obviously held a higher position, had a cubicle of his own.

Here, 'I had a table, chair and computer for my work' and 'My boss had a cubicle of his own' are independent clauses. However, 'Who obviously held a higher position' is a dependent clause. 


\section{B. On the Basis of Purpose:}

According to purpose, the sentences can be classified according to Johnson and Fillmore (2010:24) as:

\section{Declarative Sentences}

The most common type of a sentence, a declarative sentence makes a statement or declaration and hence, ends with a period or full stop. Some examples are 'The house will be built on a hill.', 'Rice is a popular food.', and 'I am going home.'

\section{Interrogative Sentences}

An interrogative sentence is one that is framed to ask or gather information. Thus, an interrogative sentence ends with a question mark. For example: 'Is it raining?', How many farmers are there in India?', and 'When are you going to work?' are all interrogative sentences.

\section{Exclamatory Sentences}

Sentences used to express strong emotions, feelings or excitement, are known as exclamatory sentences. For instance, 'The house is on fire!', 'Wow, what a wonderful day!', and 'The monster is attacking!' are exclamatory sentences.

\section{Imperative Sentences}

Sentences that indicate commands or polite requests are termed as imperative sentences. 'Close the door.', 'Please be quiet.', and 'Go to work at 7.30 tomorrow morning.' are some examples of imperative sentences.

7.2 Tenses: According to Johnson and Fillmore (2010: 25-7), they presented tenses as follows:

\section{Present continuous: I'm doing}

for temporary actions 
1. I'm in the middle of doing something. I have started doing it but I have not finished it e.g. please do not disturb me I am working

2. The action is not necessary at the same time of speaking e.g. I am reading a book at the moment I will lend it to you when I have finished it.

3. Changing of situation e.g. the population of the world is rising very fast.

4. Self arrangement e.g. at 11:00 I am watching TV.

\section{Present simple: I do}

For permanent actions:

1. Present simple is used to talk about things happened in general. e.g. the earth goes round the sun.

2.Present simple is used to say how often things are happened.

3. To express sequence of events: e.g. first do A, then do B.

4.With expressions as in I promise and I apologize.

5. Others arrangement: e.g. At 9:00 news is presented.

6. The base form of the verb functions as the present tense e.g. study

7. The present simple verb takes "s"or "es"when the subject is $3{ }^{\text {rd }}$ person singular "he, she and it"

\section{Present Perfect: I have done}

1. This tense is used when there is connection with now

e.g. Where is your key? I don't know. I've lost it

2. This tense is used to give new information or to announce recent happening e.g. Ow! I've cut my finger.

3. Present perfect with just, already, and yet. 
4. This tense is used to talk about a period of time that continues from past until now and with periods that continues till the time of speaking e.g. Have you had a holiday this year?

\section{Present Perfect Continuous Tense: Have /has+been+verb -ing}

This tense is used:

1. for an action which began in the past and still continuing e.g. I have been expecting a call from Mary all day.

2. with verbs which have the meaning of prolonged action as "live, wait,

4. for actions which have just finished. e.g. you are out of breath. Have you been running?

\section{Past simple: I did}

This tense is used to refer to past action. It is very often to use regular verbs that ends in -ed, as stopped, at the same time irregular verbs is used also as wrote.

This tense is used to write biography and to state sequence of event. e.g. I was walking along the road when I saw Dave. So I stopped and we had a chat.

\section{Past continuous: was/were+ing}

This tense is used to say that somebody was in the middle of doing something at certain time. The action or situation had already started before but had not ends

We often use past simple and past continuous together to say that something happened in the middle of something else.

\section{Past perfect:}

This tense is used to refer to two actions one of them started at the end of another e.g. Sarah went to a party last week. Paul went to the party too but

They did not see each other. Paul went home at 10:30 and Sarah arrived at 11 o'clock so: When Sarah arrived at the party, Paul was not there. He had gone home. 


\section{Past Perfect Continuous: had + been $+v$-ing}

This tense is used as:

1. for repeated action in the past implying continuity e.g. He had been trying to get her on the phone for two hours.

2. for a continuous past action completed before another past action e.g He had been driving all day, so he felt very tied when he arrived home.

\section{Future tense: Will+ verb infinitive}

This tense is used:

1. for a simple statement of future fact e.g. Staying in this hotel will cost you a fortune.

2. to express speaker's opinion, assumptions, speculations, doubt, hopes, fears, about the future. These may be introduced by verbs as think, know, and believe.

3. for habitual actions which will take place in the future.e.g. Spring will come again.

4. to express willingness or intention particularly at the moment of decision e.g. I will wait for you.

5. 'will' can be used in the first person to express:

a promise: I will remember to buy you a present.

b. Determination: we'll go to the cinema tonight.

c. 'shall', used as above, is still found in formal English, but is no longer common in conversation instead 'will' is used as in I shall be 20 next month.

6. 'shall', however, is still used in interrogative:

7. in question tag after let's as in Let's go for a walk, shall we?

8. In suggestion: shall we take a taxi? 
9. In request for orders or instructions in the first person singular and plural as in: What shall I take for dinner?

\subsection{Conversation Analysis:}

This model is presented by Smith (2008: 5) for conversation analysis of short stories:

1.Copresence: both narrator and listeners share the similar physical environment.

2. Visibility: narrator and listeners are visible to another.

3. Audibity: narrator and listeners communicate by speaking.

4. Contemporarily: listeners receive at roughly the same time as narrator produces.

5. Simultaneity: listeners and narrator can send and receive messages simultaneously.

6. Sequentiality: narrator's and listeners's turns cannot overlap.

7. Reviewability: listeners can review narrator's message.

8. Revisablity: listeners can revise for narrator .

\subsection{The Analysis}

Smith (2008) presents the model of short stories conversation thought these eight constrains to analyze the conversation presented by the storytellers and received by the child:

1. Copresence: both the narrator and the listeners share the same place as the sender and receiver share the same environment.

2. Visibility: both the narrator and the listener share the same environment then they are see each other.

3. Audibity: both the narrator and the listeners share the same subject matter and speak to each other by using the same speech language, here the conversation wins other speech medium such as body movement. 
4. Contemporarily: here the listeners receive the message at the same time it is produced by the narrator i.e. there is no other medium.

5. Simultaneity: i.e the narrator sends a message to the listener and vice versa and both of them understands each other.

6. Sequentiality: the narrator and the listener can only speak with only the same topic.

7. Reviewability: the listener can review the message as he or she receives.

8. Revisablity: the narrator can sent a revised message to the listener and the listener can revised the message to the narrator.

8.2. The analysis of tenses and structure according to Johnson and Fillmore (2010) can be represented in the following table:

\begin{tabular}{|c|c|c|c|c|c|c|c|}
\hline & Short story & tenses & Total & function & Total & Structure & total \\
\hline 1 & $\begin{array}{l}\text { A Birthday Bike } \\
\text { (1)Michael's birthday was } \\
\text { coming soon, so he asked his } \\
\text { dad for a bicycle so that he } \\
\text { would not need to walk to } \\
\text { school anymore. } \\
\text { (2)However, Michael's dad } \\
\text { had lost his job and did not } \\
\text { have much money. } \\
\text { (3)Michael got a book } \\
\text { instead but he did not } \\
\text { complain. (4)One bright and } \\
\text { sunny day while Michael } \\
\text { was walking past a } \\
\text { convenience store on his way } \\
\text { to school, he saw a big boy } \\
\text { on a bike. (5) The bike was } \\
\text { too small for the boy. (6)As } \\
\text { the boy was turning around } \\
\text { a corner, the bike skidded } \\
\text { on a puddle of water and } \\
\text { crashed into a lamp-post. } \\
\text { (7)The boy was a prefect in } \\
\text { Michael's school.(8) Michael } \\
\text { recognized him. (9) The } \\
\text { boy's name was William. } \\
\text { (10) William seemed to have } \\
\text { broken his leg. (11)Michael } \\
\text { picked up William's bike } \\
\text { which was not damaged and } \\
\text { rode to the nearby hospital } \\
\text { to get help. (12)A few } \\
\text { minutes later, an ambulance }\end{array}$ & $\begin{array}{l}\text { Simple } \\
\text { past: } \\
1,3,5,7,8, \\
9,10-16 \\
\text { Past } \\
\text { continuo } \\
\text { us } \\
4,6 \\
\\
\text { Past } \\
\text { perfect } \\
2\end{array}$ & $\begin{array}{l}\text { Simple } \\
\text { past: } \\
12 \\
\text { Past } \\
\text { continuous } \\
2 \\
\text { Past perfect } \\
1\end{array}$ & $\begin{array}{l}\text { declarativ } \\
\text { e } \\
1-16\end{array}$ & $\begin{array}{l}\text { Declarative } \\
16\end{array}$ & $\begin{array}{l}\text { Simple } \\
5,7-10,15 \\
\text { Complex } \\
1,4,13,16 \\
\text { Compound } \\
2,3,6,12,14 \\
\\
\text { Compound- } \\
\text { complex } \\
11\end{array}$ & $\begin{array}{l}\text { Compoun } \\
\text { d } \\
5 \\
\\
\text { Compoun } \\
\text { d- } \\
\text { complex } \\
1\end{array}$ \\
\hline
\end{tabular}




\begin{tabular}{|c|c|c|c|c|c|c|c|}
\hline & $\begin{array}{l}\text { came and brought William } \\
\text { to the hospital. (13)Michael } \\
\text { rode William's bike to } \\
\text { school so he would not be } \\
\text { late for class. } \\
\text { (14)After school, Michael } \\
\text { quickly rode the bicycle to } \\
\text { William's house with a book } \\
\text { and a jigsaw puzzle for } \\
\text { William. (15)William was } \\
\text { not too seriously hurt. } \\
\text { (16)He was discharged after } \\
\text { his leg was put in a cast. }\end{array}$ & & & & & & \\
\hline 2 & $\begin{array}{l}\text { A Trick } \\
\text { (1)It was late in the night, so } \\
\text { everybody was asleep except } \\
\text { for my brother and me. } \\
\text { (2)We decided to play a trick } \\
\text { on our parents. (3)We crept } \\
\text { into our parents' bedroom. } \\
\text { (4)I took a large sheet of } \\
\text { construction paper and drew } \\
\text { a morning scene and hanged } \\
\text { it on the window. } \\
\text { (5)Meanwhile, my brother } \\
\text { advanced the time on the } \\
\text { alarm clock to just ten } \\
\text { minutes before seven. (6)We } \\
\text { went back to our bedroom } \\
\text { and waited. (7)Soon the } \\
\text { alarm clock rang. (8) My } \\
\text { parents jumped out of bed. } \\
\text { (9)My father went to the } \\
\text { bathroom to brush his teeth } \\
\text { while my mother came over } \\
\text { to our room to wake us. } \\
\text { (10)She was surprised when } \\
\text { she found us awake and } \\
\text { laughing. (11)My parents } \\
\text { were angry and scolded us } \\
\text { for playing a trick on them } \\
\text { at such a late hour and for } \\
\text { waking them up. } \\
\text { (12)Nowadays they locked } \\
\text { their bedroom door when } \\
\text { thy go to bed. } \\
\end{array}$ & $\begin{array}{l}\text { Past } \\
\text { simple } \\
1-12\end{array}$ & $\begin{array}{l}\text { Past simple } \\
12\end{array}$ & $\begin{array}{l}\text { Declarativ } \\
\text { e } \\
1-12\end{array}$ & $\begin{array}{l}\text { Declarative } \\
12\end{array}$ & $\begin{array}{l}\text { Simple } \\
2,3,5,6,7,8, \\
\text { Complex } \\
1,9,10,12 \\
\\
\text { Compound } \\
4,11\end{array}$ & $\begin{array}{l}\begin{array}{l}\text { Simple } \\
6 \\
\\
\text { Complex } \\
4\end{array} \\
\text { Compoun } \\
\text { d } \\
2\end{array}$ \\
\hline 3 & \begin{tabular}{|l|} 
A Scary Night \\
(1)It was a dark and stormy \\
night. (2)I was about to go to \\
bed when I heard a tapping \\
sound on my \\
window.(3)Who's there?" I \\
shouted. (4) Suddenly there \\
was a flash of lightning; (5)I \\
saw a face at the window. \\
(6)It looked like an alien ... \\
an alien that I had seen on \\
the television show, "the X \\
\end{tabular} & $\begin{array}{l}\text { Past } \\
\text { simple } \\
1,2,3,4- \\
\text { 12,14-31 } \\
\text { Present } \\
\text { simple } \\
\text { 32 } \\
\text { Past } \\
\text { continuo } \\
\text { us } \\
13\end{array}$ & $\begin{array}{l}\text { Past simple } \\
28 \\
\text { Present } \\
\text { simple 1 } \\
\text { Past } \\
\text { continuous1 }\end{array}$ & $\begin{array}{l}\text { Question } \\
\mathbf{3}\end{array}$ & \begin{tabular}{|l|} 
Question \\
1
\end{tabular} & $\begin{array}{l}\text { Simple } \\
1,3,4,5.7,12, \\
13,16 \\
17,18,20,21, \\
23,25,26,32 \\
\\
\text { Complex } \\
2,6,10,27,29, \\
31\end{array}$ & $\begin{array}{l}\text { Simple } \\
16 \\
\\
\\
\text { Complex } \\
6\end{array}$ \\
\hline
\end{tabular}




\begin{tabular}{|c|c|c|c|c|c|c|c|}
\hline & $\begin{array}{l}\text { files."(7)I felt very scared. } \\
\text { (8) I ran to my bed and } \\
\text { pulled my blanket over my } \\
\text { head. (9)I started to shout } \\
\text { for my parents but there was } \\
\text { no reply. (10)Then I } \\
\text { remembered that they were } \\
\text { at a fancy dress party(11)I } \\
\text { peeped out of my blanket } \\
\text { but it was too dark to see } \\
\text { anything. (12) Then I heard } \\
\text { footsteps. (13)They were } \\
\text { getting louder and louder. } \\
\text { (14) It was dark but I knew } \\
\text { the way to my drawer where } \\
\text { I kept my camera. (15) I ran } \\
\text { there and took out my } \\
\text { camera and started to take } \\
\text { pictures in the direction of } \\
\text { the window. (16)Soon the } \\
\text { footsteps died off.(17)The } \\
\text { grandfather clock struck ... } \\
\text {... (18)It was } 12 \text { midnight. } \\
\text { (19)I went back to my bed } \\
\text { and tried to sleep. (20) But I } \\
\text { could not sleep. (21) I felt } \\
\text { too(22) I woke up only after } \\
\text { eight and decided to } \\
\text { investigate. (23) I found } \\
\text { some footprints outside my } \\
\text { bedroom window. (24) I } \\
\text { measured them with a tape } \\
\text { and found them to be exactly } \\
\text { the same size as my father's } \\
\text { shoes. (25)The footprints } \\
\text { ended at the door of my } \\
\text { house. (26)I then went to } \\
\text { town to get the film } \\
\text { developed. (27) But when I } \\
\text { saw the photos I was } \\
\text { shocked. (28)They were } \\
\text { black and I could hardly see } \\
\text { anything. (29) Then I } \\
\text { remembered that I did not } \\
\text { use the flash. (30)When I } \\
\text { reached home I told my } \\
\text { father the whole incident } \\
\text { and he started to laugh. (31) } \\
\text { I started laughing too when } \\
\text { he told me that he had } \\
\text { dressed up as an alien for } \\
\text { the party. (32)Today, I am } \\
\text { still amused to think I was so } \\
\text { afraid of my own father } \\
\end{array}$ & & & & & \begin{tabular}{|l|} 
Compound \\
8,9,11,14,15, \\
$19,22,24,28$, \\
\\
Compound \\
complex \\
30
\end{tabular} & $\begin{array}{l}\text { Compoun } \\
\text { d } \\
9 \\
\\
\\
\text { Compoun } \\
\text { d complex } \\
1\end{array}$ \\
\hline 4 & $\begin{array}{l}\text { Adventure at Sea } \\
\text { (1)I am the captain of a ship } \\
\text { from the Singapore Marine } \\
\text { Police Force. (2) I have been } \\
\text { with the Marine Force for } \\
\end{array}$ & $\begin{array}{l}\text { Present } \\
\text { simple } \\
1 \\
\text { Present }\end{array}$ & $\begin{array}{l}\text { Present } \\
\text { simple } \\
1 \\
\text { Present }\end{array}$ & $\begin{array}{l}\text { Declarativ } \\
\text { e } \\
1,18\end{array}$ & $\begin{array}{l}18 \\
\text { declarative }\end{array}$ & \begin{tabular}{|l|} 
Simple \\
$1,2,5,7,9,10$, \\
17,18
\end{tabular} & $\begin{array}{l}\text { Simple } \\
8\end{array}$ \\
\hline
\end{tabular}




\begin{tabular}{|c|c|c|c|c|c|c|c|}
\hline & $\begin{array}{l}\text { eight years. (3)I loved the } \\
\text { sea because of the cool sea } \\
\text { winds, the fresh smell of the } \\
\text { sea and the beautiful } \\
\text { scenery. (4) I also wanted to } \\
\text { catch criminals and so I } \\
\text { joined the Marine Police } \\
\text { Force and do what I love. } \\
\text { (5)Recently, I was out on a } \\
\text { boat with a few of my } \\
\text { friends. (6)We were not } \\
\text { working but the Marine } \\
\text { Police Force allowed us to } \\
\text { use the sailboat that was } \\
\text { meant for rest and } \\
\text { recreation. (7)We went } \\
\text { fishing.(8) We were on our } \\
\text { way back when I spotted a } \\
\text { ship with the name PSS } \\
\text { Pollu. (9) It was releasing oil } \\
\text { into the sea. (10) I was } \\
\text { horrified. (11)I picked up a } \\
\text { loud hailer and shouted, } \\
\text { "Stop your pollution at once } \\
\text { and follow us back to } \\
\text { shore!" But PSS Pollu } \\
\text { decided to flee. (12)We gave } \\
\text { chase but their ship was too } \\
\text { fast for us. (13)We contacted } \\
\text { the Marine Force base and } \\
\text { requested for help. (14)Two } \\
\text { fast marine boats were sent } \\
\text { and soon caught up with } \\
\text { PSS Pollu and surrounded } \\
\text { it. (15) The ship had no } \\
\text { choice but to surrender. } \\
\text { (16)Six marine policemen } \\
\text { searched PSS Pollu and } \\
\text { discovered that it was } \\
\text { carrying smuggled } \\
\text { cigarettes. (17)The men of } \\
\text { PSS Pollu were subsequently } \\
\text { charged in court. (18)I was } \\
\text { rewarded for responding to } \\
\text { a situation while off duty. }\end{array}$ & $\begin{array}{l}\text { perfect } \\
2 \\
\text { Past } \\
\text { continuo } \\
\text { us } \\
9 \\
\\
\text { Past } \\
\text { simple } \\
\text { 3-8, 10- } \\
18\end{array}$ & $\begin{array}{l}\text { perfect } \\
1 \\
\text { Past } \\
\text { continuous } \\
1 \\
\text { Past simple } \\
15\end{array}$ & & & \begin{tabular}{|l|} 
Compound \\
$4,6,12-16$ \\
\\
Complex \\
3,8,11
\end{tabular} & $\begin{array}{l}\text { Compoun } \\
\text { d } \\
7 \\
\text { Complex } \\
3\end{array}$ \\
\hline 1 & $\begin{array}{l}\text { A Duck Tale } \\
\text { (1)The bright morning rays } \\
\text { shone through the bedroom } \\
\text { curtains onto Farmer } \\
\text { Huang's pillow; making the } \\
\text { room hot and stuffy. (2) } \\
\text { Farmer Huang is not an } \\
\text { early riser but the heat woke } \\
\text { up him. (3) He hurriedly got } \\
\text { up and started to head for } \\
\text { his poultry farm. (4)He had } \\
\text { invested all his money in }\end{array}$ & $\begin{array}{l}\text { Past } \\
\text { simple } \\
1,3,5,6,7, \\
9-21 \\
\text { Present } \\
\text { simple } \\
2 \\
\text { Past } \\
\text { continuo } \\
\text { us }\end{array}$ & $\begin{array}{l}\text { Past simple } \\
22 \\
\text { Present } \\
\text { simple } \\
1 \\
\text { Past } \\
\text { continuous } \\
1 \\
\text { Past perfect }\end{array}$ & $\begin{array}{l}\text { declarativ } \\
\text { e } \\
1- \\
9,11,12,14, \\
15,17-21 \\
\text { Exclamati } \\
\text { on } \\
10,16 \\
\text { Question }\end{array}$ & $\begin{array}{l}\text { Declarative } \\
18 \\
\text { Exclamatio } \\
\text { n } \\
2 \\
\text { Question } \\
1\end{array}$ & \begin{tabular}{|l|} 
Simple \\
$1,4,10$, \\
$12,13,14$, \\
$17,18,19,21$ \\
\\
Complex \\
$2,5,6,7,16$ \\
\\
\\
Compound \\
$3,8,9,11,15,2$ \\
\end{tabular} & $\begin{array}{l}\text { Simple } \\
10\end{array}$ \\
\hline
\end{tabular}




\begin{tabular}{|c|c|c|c|c|c|c|c|}
\hline & $\begin{array}{l}\text { ducks.(5)Farmer Huang got } \\
\text { into his lorry that was } \\
\text { loaded with ducks in cages } \\
\text { and his two workers, Bill } \\
\text { and Jim. (6) Their first stop } \\
\text { was City Primary School. } \\
\text { So, upon reaching the school } \\
\text { gate, the lorry skidded and } \\
\text { punctured a tyre. (7)Farmer } \\
\text { Huang left his workers to } \\
\text { change the tyre while he } \\
\text { went into the school canteen } \\
\text { to hand over some ducks. } \\
\text { (8)Meanwhile, a boy had } \\
\text { crept up the lorry and } \\
\text { opened some of the cages. } \\
\text { (9)Jim happened to look up; } \\
\text { the boy jumped down from } \\
\text { the lorry and ran into the } \\
\text { school compound. (10) The } \\
\text { ducks were escaping! } \\
\text { (11)Jim and Bill hurriedly } \\
\text { tried to get the ducks back } \\
\text { into the cages but their } \\
\text { efforts were in vain. (12) } \\
\text { There was a great } \\
\text { commotion ... ducks } \\
\text { quacking, workers shouting. } \\
\text { (13)Where was the naughty } \\
\text { boy? (14)He was at the } \\
\text { school gate letting some } \\
\text { ducks into the school. } \\
\text { (15)On hearing the noise, } \\
\text { many children came out of } \\
\text { their classrooms and were } \\
\text { watching the funny sight ... } \\
\text { two men chasing ducks } \\
\text { which were quacking.(16) } \\
\text { waddling and flapping their } \\
\text { wings which in turn sent } \\
\text { down feathers floating in the } \\
\text { air! (17)It was hilarious. } \\
\text { (18)Farmer Huang came } \\
\text { back just in time to catch } \\
\text { hold of the boy. (19)He then } \\
\text { went after the ducks. (20)He } \\
\text { made a funny quacking } \\
\text { sound and the ducks began } \\
\text { to come to him. (21) He } \\
\text { happily put them back into } \\
\text { their cages, changed the } \\
\text { punctured tyre and drove } \\
\text { off ... leaving the boy in the } \\
\text { hands of the school } \\
\text { principal. }\end{array}$ & $\begin{array}{l}10 \\
\\
\text { Past } \\
\text { perfect } \\
\mathbf{4 , 8},\end{array}$ & 2 & 13 & & 0 & $\begin{array}{l}\text { Compoun } \\
\text { d } \\
6\end{array}$ \\
\hline & Short story & tenses & total & function & total & structure & total \\
\hline 2 & $\begin{array}{l}\text { A Mouse and His Bug } \\
\text { (1)Once there was a mouse } \\
\text { who lived in a great big }\end{array}$ & $\begin{array}{l}\text { Past } \\
\text { simple } \\
1-6\end{array}$ & $\begin{array}{l}\text { Past simple } \\
6\end{array}$ & $\begin{array}{l}\text { Declarativ } \\
\text { e } \\
1-6\end{array}$ & $\begin{array}{l}\text { Declarative } \\
6\end{array}$ & $\begin{array}{l}\text { Simple } \\
\text { 0 }\end{array}$ & $\begin{array}{l}\text { Simple } \\
0\end{array}$ \\
\hline
\end{tabular}




\begin{tabular}{|c|c|c|c|c|c|c|c|}
\hline & $\begin{array}{l}\text { house.(2)The mouse had a } \\
\text { pet bug which lived in his } \\
\text { mug.(3)The mouse wasn't } \\
\text { very happy when his bug } \\
\text { jumped into his favourite } \\
\text { rug(4).The mouse made the } \\
\text { bug stay in his mug and } \\
\text { orbade it to go near the rug. } \\
\text { (5)The bug just wouldn't } \\
\text { listen and jumped onto the } \\
\text { rug(6)This time, the mouse } \\
\text { was furious and squashed it } \\
\text { with his mug }\end{array}$ & & & & & $\begin{array}{l}\text { Complex } \\
1,2,3, \\
\\
\text { Compound } \\
4,5,6,\end{array}$ & $\begin{array}{l}\text { Complex } \\
3 \\
\text { Compoun } \\
\text { d3 }\end{array}$ \\
\hline 3 & $\begin{array}{l}\text { Sharing with one another } \\
\text { (1)Once upon a time, there } \\
\text { were two sheep. (2)One was } \\
\text { a small sheep ... so small } \\
\text { (separate hands to show } \\
\text { size). (3) It has a soft voice ... } \\
\text { baa! (4)The other was a big } \\
\text { sheep ... so big (stretch arms } \\
\text { to show size). (5) It has a } \\
\text { loud voice ... BAA! (6)The } \\
\text { two sheep are brothers. } \\
\text { (7)Every day, Big Sheep and } \\
\text { Small Sheep would go out to } \\
\text { the fields to play together } \\
\text { and to look for grass to eat. } \\
\text { (8)One morning, as always, } \\
\text { the two sheep went out. } \\
\text { (9)Big Sheep and Small } \\
\text { Sheep gambolled out to the } \\
\text { fields to look for grass to eat } \\
\text {... ((10)Get the children to } \\
\text { gambol together "to the } \\
\text { fields.") (11) Now it has not } \\
\text { been raining for many days } \\
\text { and most of the grass had } \\
\text { dried up. (12)Big Sheep and } \\
\text { Small Sheep gambolled for a } \\
\text { long time but they could not } \\
\text { find any green grass to eat. } \\
\text { (13)They were getting tired. } \\
\text { (14) Their feet were tired } \\
\text { and they could no longer } \\
\text { gambol. (15)So they walked } \\
\text {... ((16)Get the children to } \\
\text { drag their feet on the } \\
\text { ground.) (17)Big Sheep and } \\
\text { Small Sheep walked and } \\
\text { walked from morning until } \\
\text { afternoon but there were no } \\
\text { green grass. (18) As far as } \\
\text { they could see all the green } \\
\text { grass had become brown. } \\
\text { (19)The sun was getting } \\
\text { hotter. (20)Big Sheep and } \\
\text { Small Sheep were tired, } \\
\text { hungry and thirsty ... }\end{array}$ & $\begin{array}{l}\text { Past } \\
\text { simple } \\
1,2,4,7,8, \\
9,10,12,1 \\
4,15- \\
20,22,23, \\
25- \\
34,39,40, \\
42,43,46, \\
47,49 \\
\\
\text { Present } \\
\text { simple } \\
3,5,6,11, \\
16,21,24, \\
36,37,38, \\
41,45 \\
\\
\\
\text { Past } \\
\text { continuo } \\
\text { us } \\
13,44,\end{array}$ & $\begin{array}{l}\text { Past simple } \\
34 \\
\\
\text { Present } \\
\text { simple } \\
12 \\
\\
\text { Past } \\
\text { continuous } \\
2\end{array}$ & $\begin{array}{l}\text { Exclamati } \\
\text { on } \\
3,5,28,35,3 \\
8\end{array}$ & $\begin{array}{l}\text { Declarative } \\
34 \\
\text { Exclamatio } \\
\text { n } \\
5 \\
\text { Imperative } \\
8 \\
\text { Question } \\
2\end{array}$ & $\begin{array}{l}\text { Simple } \\
1-6,8- \\
11,13,15,16, \\
18- \\
12,24,26,27- \\
29- \\
34,36,38,39 \text {, } \\
41,43,44,46, \\
48 \\
\text { Complex } \\
17,25,47,49 \\
\\
\text { Compound } \\
7,12,14,22,2 \\
3,40,42,37,4 \\
5\end{array}$ & $\begin{array}{l}\text { Complex } \\
4,\end{array}$ \\
\hline
\end{tabular}


((21)Get the children to stick out their tongues and pant.) (22)But Big Sheep and Small Sheep continued walking and soon they came to a river. (23) They lowered their heads and lapped up some water with their tongue ... ((24)demonstrate how this is done). (25)When Big Sheep lifted his head, he saw a small green patch under a tree. (26)He gambolled over to the tree. (27) It was a patch of green grass. (28)"BAA, BAA!" (29)he shouted to Small Sheep to come over. (30)Both Big Sheep and Small Sheep were very excited. (31) But the small patch of grass was a very small patch ...(32) it was just enough for one sheep.

(33)What should they do? (34) (Pause) Who should eat the small batch of green grass? (35) (Pause) "BAA, BAA! (36) Go ahead and eat it. (37) I am not very hungry" said Big Sheep and he began to move away. (38) "Baa! Let us share the green grass" said Small Sheep. (39)So Big Sheep and Small Sheep shared the small patch of small grass. (41)They were very happy and they gambolled all the way home ... ((42)Get the children to hold hands and gambol "all the way home.") (43)Big Sheep found the green grass and he could have eaten the grass all by himself. (44) But Big Sheep was generous to let Small Sheep eat the small patch of green grass. (45)Small Sheep was also sharing ... he shared the green grass with Big Sheep. (46)Small Sheep loves Big Sheep and Big Sheep loves Small Sheep. (47)It was a dark and stormy night. (48)I was about to go to bed when I heard a tapping sound on my window.(49)It was a 


\begin{tabular}{|c|c|c|c|c|c|c|c|}
\hline & $\begin{array}{l}\text { dark and stormy night. (50)I } \\
\text { was about to go to bed when } \\
\text { I heard a tapping sound o }\end{array}$ & & & & & & \\
\hline & $\begin{array}{l}4 \text { Woa Woa and A Wagging } \\
\text { Tail } \\
\text { (1)Every evening, Blackie } \\
\text { would be waiting for Alan to } \\
\text { come back from school. } \\
\text { (2)Blackie was always very } \\
\text { happy to see Alan. (3) He } \\
\text { would greet Alan with a woa } \\
\text { woa and a wagging tail. (4) } \\
\text { Blackie was a dog and Alan } \\
\text { was his master. (5) Blackie } \\
\text { liked to play with Alan. } \\
\text { (6)One evening when Alan } \\
\text { returned from school, there } \\
\text { was no woa woa and a } \\
\text { wagging tail. Blackie was } \\
\text { missing. (7)Early the next } \\
\text { morning, Alan and his } \\
\text { brother and two sisters went } \\
\text { to look for Blackie. (8) They } \\
\text { walked and searched ... } \\
\text { shouting "Blackie, Blackie!" } \\
\text { (9)They walked and } \\
\text { searched from morning to } \\
\text { evening ... shouting } \\
\text { "Blackie, Blackie!" (10) But } \\
\text { there was no woa woa and a } \\
\text { wagging tail. (11) The } \\
\text { children were very sad and } \\
\text { tired. (12)One day, the } \\
\text { children heard a woa woa } \\
\text { coming from a house. (13)It } \\
\text { sounded like Blackie. } \\
\text { (14)The children ran to the } \\
\text { house and rang the bell. A } \\
\text { man opened the door. } \\
\text { (15)The children asked, } \\
\text { "Uncle, have you seen a } \\
\text { black dog?" (16) The man } \\
\text { replied, "No." (17)But the } \\
\text { children could still hear a } \\
\text { woa woa coming from the } \\
\text { house. (18)The children } \\
\text { decided to climb a small hill } \\
\text { that leads to the back of the } \\
\text { house. (19)It was not easy to } \\
\text { climb the hill. (20)They had } \\
\text { to hold on to twines and pull } \\
\text { themselves up the slope. } \\
\text { (21)When the children } \\
\text { reached the top and looked } \\
\text { down at the house, they were } \\
\text { very excited. (22)There was } \\
\text { Blackie tied to a chain. } \\
\text { (23)The children hurried }\end{array}$ & $\begin{array}{l}\text { Past } \\
\text { simple 1- } \\
31\end{array}$ & $\begin{array}{l}\text { Past simple } \\
31\end{array}$ & $\begin{array}{l}\text { Exclamati } \\
\text { on } \\
8,9,30 \\
\text { Question } \\
15,25 \\
\\
\text { Declarativ } \\
\text { e1-14,16- } \\
24,2629,31\end{array}$ & $\begin{array}{l}\text { Exclamatio } \\
\mathbf{n} \\
\mathbf{3} \\
\text { Question } 2 \\
\text { Declarative } \\
27\end{array}$ & $\begin{array}{l}\text { Simple1,2,3, } \\
, 5,7-13,15- \\
16,17,19,22, \\
23,25,26, \\
27,28,30, \\
\\
\\
\text { Complex } \\
6,18,21,29 \\
\\
\\
\text { Compound } \\
4,14,20,24,3 \\
1\end{array}$ & $\begin{array}{l}\text { Complex } \\
\mathbf{4} \\
\text { Compoun } \\
\text { d } \\
\mathbf{5}\end{array}$ \\
\hline
\end{tabular}




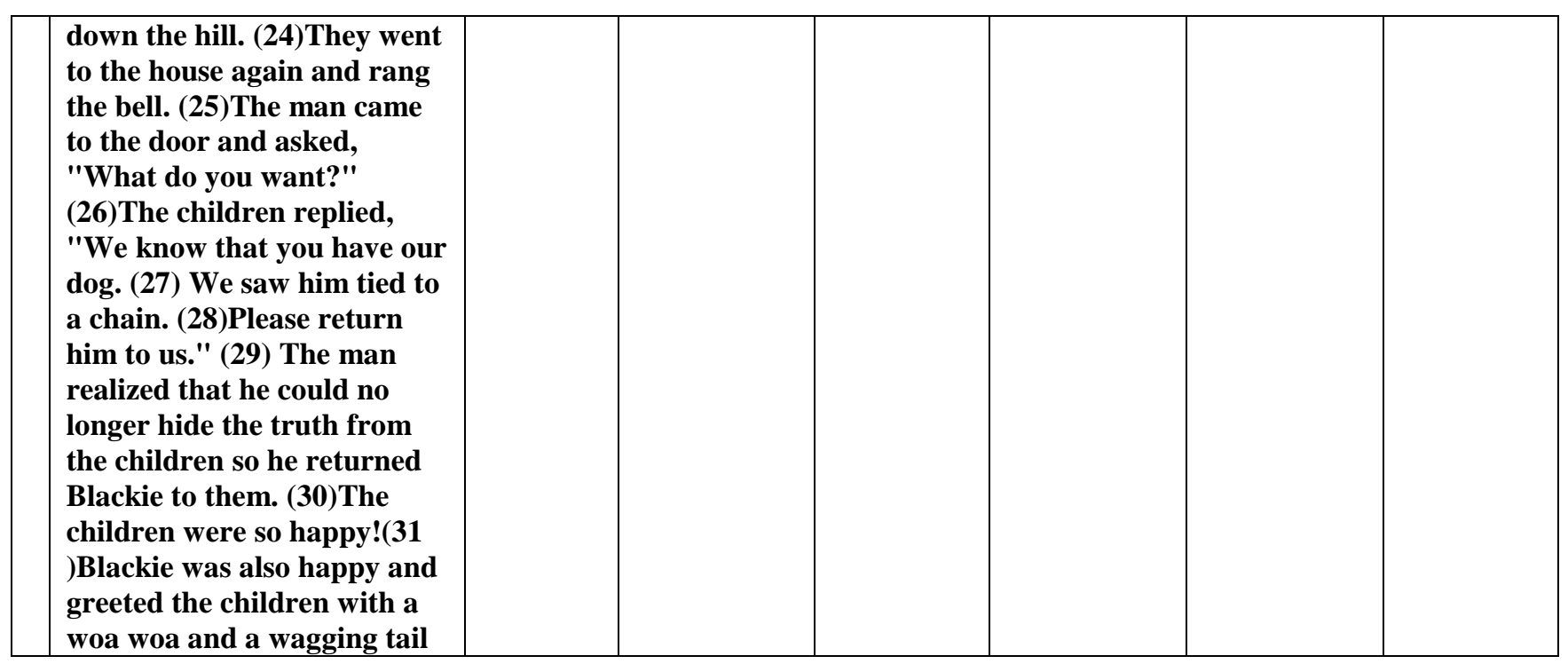

\section{Results and Discussion:}

According to the previous table, the result of the analysis of four short stories for children of four years old and those of children of six years old show different scores of frequency for grammatical tenses as follows: for children of four years old 70 past simple, 2 for present simple, 4 for past continuous, 1 for past perfect whereas tenses for 6 years old is 89 past simple, 13 present simple, 3 past continuous, 2 past perfect. This shows that the older children depend on grammatical issues more than younger children. For functional categories for children of four years old, 46 declarative and 1 question whereas older children depends on 96 declarative, 9 exclamation, 3 question, 6 imperative. This also shows different grammatical issues depending on the age. For the structure, for children of four years old: simple sentence 36, 14 complex sentences, 23 compound sentence, 2 compound complex sentences. For younger children, 66 simple sentence, 16 complex sentence, 23 compound sentences.

This study postulate similarities between natural conversation and conversation in short stories that is due to the categories of grammatical issues will be so long then the short story will be short as in (A Mouse and his bug) and the short story as long as (sharing with one other).

The story tellers use simple language when they tell the story in order to attract the children attention to the message inside the story in smooth way.

According to Smith (2008) there are similarities between language in children's short stories and short stories in general. 


\section{Conclusion:}

The following conclusions can be drown:

1. The frequency of categories through the study shows that past simple has higher score of the study and for function declarative has higher frequency than the others. This is due to the age of the children.

2. It is noted that question and other categories rather than declarative is few for both younger and older children. This is due to the reason of short story which informs new information.

3. Simple sentences are used more than the others. This is due to the age of children.

4. It can be noticed that there is similarities between real language and short stories language throughout the length of sentences depending on the used devices.

5. The short stories depend on simple language to transfer the message inside the story to the child in a spontaneous way and to attract the children attention to the message inside the story in smooth way.

6. According to Smith (2008) there are similarities between language in children's short stories and short stories in general. 


\section{References:}

- Applebee,N.A.(1978)The Child's Concept of Story: Ages two to Seventeen.Chicago:university of Chicago press

- Cain,k and Oakhillj(1990) "The Nature of the Relationship between Comprehension Skill and the Ability to tell a Story British" Journal of Developmental Psychology p187-201

- Dodsworth (1990) "conversational organization: interaction between speakers and hearers, Cambridge: CUP

- Fluedmik,Monika(2012) "Conversational Narration -Oral Narration" $<$ hup.sub.uni-homburge.de>retrieved on 3/8/2014

- Johnstone,Barbara (2001) "Discourse Analysis and Narrative" in the Handbook of Discourse Analysis, Sciffrin ,Deborah;Tannen,Deborah and Hamilton, Heihi(eds).New york: Blackwell

- Johnstone,S.(2010) "Syntactic Analysis of Short Stories" (www.melta.org.my) retrieved on $3 / 8 / 2014$

- Labov,W(1972)Language in the Buner. City Philadelphia: University of Pennsylvania

- Liles,A(1971)Interaction and grammar in British English.Mouton:the Hugue

- Murray,J.D.(1997) "Connectives and Narrative Text: the Role of Contritely Memory and cognition" p277-236

- Peterson.C and McCabe,A(1997)Linking Children's Connectives Use and Narrative Macrostructure in Mc Cabe and Peterson(eds) Developing Narrative Structure: Hillsdale and Njerlbaun P29-53

- Peterson.C and Dodsworth ,P(1991) "Longitudinal Analysis of Young Children Cohesion and noun Specification in narratives" :Journal of Child Language .18,397-415

- Shapiro and Hudson (1997) "Some functions of gaze -direction in social interaction" Vol.26,PP22-36

- Smith,Z(2008) "Analyzing conversation in short stories" (www.melta.org.my) retrieved on 3/8/2014

- Yuill , N and Joscelyne, T(1988) "Effect of Organizational Cue and Strategies on Good and Poor Comprehension Story Understanding”. Journal of Educational Psychology.vol. 30:152-158 


\title{
تحليل المحادثة في قصص الاطفال القصيرة \\ مانغم علي حسن \\ جامعة بغداد/ كلية الهندسة
}

\begin{abstract}
الملخص:
إنَّ تحليل المحادثات كانت الثغل الثشاغل لكثير من علماء اللغة و المهتمين بدراسة تحليل الخطابة.

بالرغم من ان عدة دراسات قد تمت في مجال القصة القصيرة الا ان القصص القصيرة المختارة" لم تدرس. و و لهذاء فان هذا البحث يروم الى دراسة هذه الثغرة. يهدف هذا البحث الى جواب الاسئلة التالية: ماهي صفات التهات اللغة في القصص القصيرة للأطفال. وماهي الاختلافات بينها في عمر اربع سنوات وتلك التي تحصل في الست سنوات. هذا يتطلب دراسة الادوات المستخدمة في رواية القصص. استخدمت الباحثة كلا من جونسن وفلمور (· ( ب)

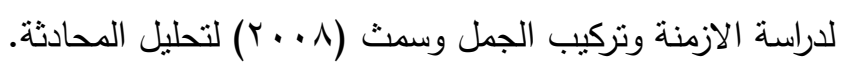
وفي ضوء الدراسة التحليلية التي قامت بها الباحثة اصبح من الواضح استخدام الجمل البسيطة والزمن الماضي البسيط اكثر من بقية الادوات. ويعود سبب ذللك الى ان الصفات الرئيسية للغة الاطفال تعتمد عليها.

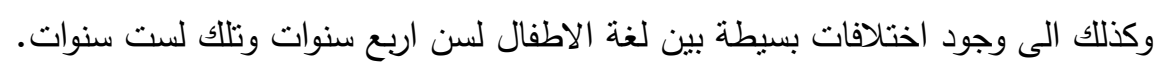

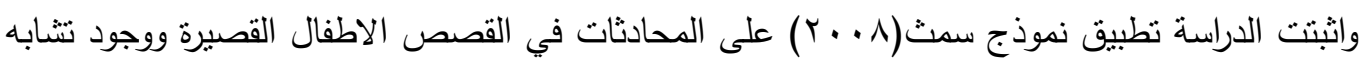
بين لغة القصص للأطفال ولغة القصص بشكل عام .
\end{abstract}

